\title{
ANALISIS KEBIJAKAN DALAM MENGAMANKAN PULAU MIANGAS PROVINSI SULAWESI UTARA
}

\author{
Heru Dian Setiawan \\ Dosen Fakultas Ilmu Sosial dan Ilmu Politik \\ Universitas Nasional Jurusan Administrasi Negara \\ Email: konman_hds@yahoo.com
}

\begin{abstract}
ABSTRAK
Kajian ini dilatar-belakangi oleh semakin tingginya ancaman keamanan dan pertahanan di wilayah perbatasan Indonesia. Pasca lepasnya pulau Sipadan dan Ligitan pada tanggal 17 Desember 2002 merupakan salah satu pembelajaran sangat penting bagi Indonesia untuk tidak mengulangi kesalahan yang sama, dan untuk menghindari terjadinya kembali konflik antar Negara tetangga. Oleh karenanya, dengan menggunakan metode kajian yang berproses deskriptif kualitatif berdasar pada konsep Kartasasmita (1997:142) dan Anderson (dalam Islamy, 1994:20-21), maka kajian ini bertujuan untuk mengetahui upaya-upaya kebijakan Pemerintah Indonesia dalam mengamankan Pulau Miangas Provinsi Sulawesi Utara.
\end{abstract}

Kata kunci : Kebijakan, Konflik Antar Negara, Teritory

\section{ABSTRACT}

This study is based on the higher security and defense in the territory of Indonesia. After the release of Sipadan and Ligitan Islands on December 17, 2002 is one of the most important lessons for Indonesia not to repeat the same mistakes, and to avoid re-conflicts between neighboring countries. Therefore, using a qualitative study method based on the concept of Kartasasmita (1997: 142) and Anderson (in Islamy, 1994: 20-21), this study aims to find out the Government of Indonesia's policy efforts in the security of Pulau Miangas North Sulawesi Province.

Key words: Policy, Inter-State Conflict, Territory

\section{A. Latar Belakang}

Perbatasan wilayah laut Indonesia beserta pulau-pulaunya yang berbatasan langsung dengan negara lain kerap kali mengalami kondisi yang cukup rawan terhadap berbagai ancaman keamanan dan tindakan kriminal, khususnya perbatasan wilayah laut pulau terluar Indonesia yang memiliki arti strategis dilihat dari konteks integrasi nasional (Widodo AS, 2007). Pasca lepasnya pulau Sipadan dan Ligitan pada tanggal 17 Desember 2002 merupakan pembelajaran sangat penting bagi Indonesia untuk tidak mengulangi kesalahan yang sama, dan untuk menghindari terjadinya kembali konflik antar Negara tetangga.

Saat ini tercatat sebanyak duabelas pulau yang berbatasan negara lain (lihat pada tabel 1) yang merupakan aset negara yang tak ternilai harganya dan bahkan 
bisa menjadi sebuah masukan bagi pendapatan negara namun dengan catatan harus memiliki pertahanan yang kuat serta ketat untuk menjaga kedaulatan negara kita ini.

Tabel 1

Pulau-Pulau Terluar Indonesia yang Berbatasan Langsung dengan Negara lain

\begin{tabular}{|l|l|c|c|c|}
\hline No. & Nama Pulau & Kota/Kabupaten & Provinsi & $\begin{array}{c}\text { Negara yang } \\
\text { Berbatasan } \\
\text { Langsung }\end{array}$ \\
\hline 1 & Pulau Rondo & Sabang & NAD & India \\
\hline 2 & Pulau Berhala & Serdang & Sumatera Utara & Malaysia \\
\hline 3 & Pulau Nipa & Batam & Kep. Riau & Singapura \\
\hline 4 & Pulau Sekatung & Natuna & Kep. Riau & Vietnam \\
\hline 5 & Pulau Marampit & Kep. Talaud & Sulawesi Utara & Philipina \\
\hline 6 & Pulau Marore & Kep. Sangihe & Sulawesi Utara & Philipina \\
\hline 7 & Pulau Miangas & Talaud & Sulawesi Utara & Philipina \\
\hline 8 & Pulau Fani & Sorong & Papua Barat & Palau \\
\hline 9 & Pulau Fanildo & Supriori & Papua & Palau \\
\hline 10 & Pulau Bras & Biak Numfor & Papua & Palau \\
\hline 11 & Pulau Batek & Atambua & NTT & Timor Leste \\
\hline 12 & Pulau Dana & Rote & NTT & Australia \\
\hline
\end{tabular}

Sumber: Kementerian Pertahanan, 2013.

Penetapan batas wilayah laut Indonesia dengan beberapa Negara tetangga sampai saat ini belum terselesaikan seluruhnya. Hal ini tentunya sangat merugikan Indonesia karena membuka celah baru bagi terjadinya berbagai tindakan kriminal dan konflik dengan Negara tetangga. Padahal kawasan perbatasan memiliki arti yang sangat vital dan strategis, baik dalam sudut pandang pertahanan-keamanan, maupun dalam sudut pandang ekonomi, sosial, dan budaya.

Dari sekian permasalahan penetapan batas wilayah laut Indonesia dengan beberapa Negara tetangga, salah satunya terjadi antara Indonesia dengan Filipina di wilayah perairan laut Sulawesi Utara. Dari sebanyak sebelas pulau, sedikitnya 3 pulau kecil terluar, yakni Miangas, Marampit, dan Marore sebagai pulau terawan yang berhadapan dengan perbatasan Filipina (Alex Retraubun, 2007). Pulau Miangas merupakan salah satu contoh kasus dari tiga pulau kecil terluar Indonesia di Provinsi Sulawesi Utara yang berpotensi konflik dengan Negara Filipina (Sadina, 2006). Adanya ancaman ideologi, politik, ekonomi, sosial dan budaya dari Filipina memunculkan isu pulau Miangas akan terlepas dari Indonesia. Dalam seminar Arah dan Strategi Pembangunan Kabupaten Talaud ke Depan di Manado, dihasilkan kesimpulan bahwa aspek hukum internasional belum sepenuhnya memberikan jaminan Pulau Miangas adalah milik Indonesia, karena Negara Filipina telah memasukkan pulau Miangas pada hukum negaranya tahun 1961, padahal secara de facto Pulau Miangas adalah milik Indonesia (Varrianto Madjowa, 2003). Dalam putusan Mahkamah Arbitrase tahun 1928 di Den Haag, dinyatakan bahwa Belanda berhak atas pulau Miangas, sehingga dengan sendirinya pulau Miangas adalah milik 
Indonesia (Paulus Londo, 2006). Sementara pihak konstitusi Filipina masih memuat Pulau Miangas sebagai bagian dari wilayahnya yang tercantum dalam beberapa versi traktat, diantaranya menurut Direktorat Kelembagaan Internasional, Departemen Kelautan dan Perikanan, 2007) sebagai berikut:

1) Traktat Paris pasal III, 10 Desember 1898, dibuat antara Amerika Serikat dan Spanyol.

2) Traktat Washington, 7 November 1900, dibuat antara Amerika Serikat dan Spanyol.

3) Traktat 27 Januari 1930, dibuat antara Amerika Serikat dan Inggris.

Berdasarkan kenyataan di atas, masalah tersebut tidak bisa dianggap sederhana dan tidak mendesak, sebab pada ketiga pulau terluar yang berbatasan langsung dengan Filipina (yaitu Pulau Miangas, Marore, dan Marampit) seringkali pula menjadi tempat penyelundupan barang, narkotika, senjata hingga manusia. Pencurian ikan oleh nelayan Filipina biasa terjadi di sekitar wilayah tersebut. Masalah lainnya adalah ketiga pulau tersebut berbatasan dengan Davau dan Mindanao (sebagai dua wilayah di Filipina) yang rawan dengan berbagai konflik. Di sana terdapat kelompok Moro Islamic Liberation Front/MILF yang melakukan pemberontakan dan menuntut kemerdekaan dari Filipina. Disana juga terdapat kelompok Abu Sayyaf, sebuah kelompok yang oleh PBB digolongkan ke dalam jaringan terorisme dan banyak melakukan aksi terorisme di Filipina. Berbagai konflik yang terjadi di wilayah Indonesia dan berbagai aksi terorisme di Indonesia ditengarai berasal dari Filipina. Kuat dugaan bahwa munculnya berbagai kejahatan yang menggunakan senjata api sebenarnya berasal dari kedua kelompok tersebut. Penyelundupan senjata dari MILF atau Abu Sayyaf ke Indonesia melalui perbatasan sudah menjadi rahasia umum.

Mengingat pengamanan pulau-pulau terluar Indonesia merupakan faktor yang sangat penting dalam menjaga kedaulatan Negara Kesatuan Republik Indonesia (NKRI), maka kajian ini bertujuan untuk mengetahui upaya-upaya kebijakan Pemerintah Indonesia dalam mengamankan Pulau Miangas Provinsi Sulawesi Utara.

\section{B. Metode Kajian}

Metode kajian dalam penelitian ini berproses deskriptif kualitatif, yang memaparkan, menganalisis, dan menafsirkan permasalahan kajian secara deskriptif untuk berupaya mencari deksripsi yang tepat dan terkait dengan objek kajian. Adapun data penelitian yang dikumpulkan adalah melalui data sekunder yang berasal dari tinjauan literatur baik berupa buku, artikel, laporan, website dan lain-lain yang relevan dengan kajian penelitian terutama mengenai kebijakan bilateral dan pembangunan kawasan perbatasan. Kemudian data yang dikumpulkan berdasar pada konsep Anderson dalam Islamy (1994:2021) dianalisis dengan menggunakan metode analisis SWOT (Strengths, Weaknesses, Opportunities, Threats) dan metode analisis perbandingan berpasangan. 


\section{Kebijakan Bilateral Antara Indonesia dan Filipina}

Konsep batas negara atau perbatasan yang sering digunakan dalam literaturliteratur merujuk dari bahasa Inggris yaitu istilah border, boundary atau frontier. Beberapa hal penting yang menjadi fokus perhatian dalam wilayah perbatasan adalah meningkatnya perhatian terhadap jaringan, mobilitas, arus globalisasi, dan kosmopolitanisasi yang berperan dalam mewarnai sifat sebuah kawasan perbatasan.

Brunnet-Jailly (dalam Ganewati Wuryandari, 2009) menyatakan, bahwa untuk menganalisis masalah perbatasan ada beberapa elemen yang perlu mendapatkan perhatian, antara lain kebijakan pemerintah Negara-negara berbatasan langsung (policyactivities of multiple levels of governments on adjacent borders). Hal ini dapat diartikan bahwa aspek kebijakan pemerintah negara-negara yang berbatasan langsung menyangkut hubungan-hubungan horizontal (antar lembaga pemerintah yang setara) dan vertikal (antar lembaga dengan hierarki otoritas berbeda: pusat, provinsi, kabupaten, kecamatan dan seterusnya). Hubungan horizontal tampak menjadi ciri tata kelola perbatasan yang bersifat "multilevel governance", seperti Uni Eropa dan ASEAN dalam pengaturan kebijakan imigrasi bersama (paspor, visa, dan lain-lain). Sementara hubungan vertical menjadi ciri kebijakan perbatasan yang disusun secara bilateral, antara dua negara yang berbatasan langsung. Kebijakan pemerintah juga dapat dibedakan berdasarkan tujuannya, antara yang memuat tujuan umum dan spesifik. Kebijakan dengan tujuan umum, biasanya dilakukan oleh lembaga-lembaga seperti kementerian pertahanan, kepolisian, kantor imigrasi, kantor bea-cukai, dan sebagainya, sedangkan kebijakan dengan tujuan spesifik, biasanya dilakukan oleh unit-unit khusus seperti patroli perbatasan, pos perbatasan, pengawas pantai (seperti misalnya US Coast Guard), dan sebagainya.

Suatu kebijakan dapat dikatakan sebagai upaya untuk memahami dan mengartikan : (1) Apa yang dilakukan (atau tidak dilakukan) oleh pemerintah mengenai suatu masalah, (2) Apa yang menyebabkan atau yang mempengaruhinya, dan (3) Apa pengaruh dan dampak dari kebijakan publik tersebut (Kartasasmita, 1997:142). Anderson (dalam Islamy, 1994:20-21) mengatakan bahwa:

a. Kebijakan selalu mempunyai tujuan atau berorientasi pada tujuan tertentu.

b. Kebijakan berisi tindakan atau pola tindakan pejabat-pejabat pemerintah.

c. Kebijakan adalah apa yang benar-benar dilakukan oleh pemerintah dan bukan apa yang bermaksud akan dilakukan.

d. Kebijakan publik bersifat positif (merupakan tindakan pemerintah mengenai suatu masalah tertentu) dan bersifat negatif (keputusan pejabat pemerintah untuk tidak melakukan sesuatu).

e. Kebijakan publik (positif) selalu berdasarkan pada peraturan perundangan tertentu yang bersifat memaksa (otoratif).

Kebijakan bilateral antara Indonesia dan Filipina didasari oleh keduanya merupakan negara kepulauan dan memiliki komposisi penduduk etnis yang berkerabat dalam kesatuan keturunan Austronesia. Hubungan sejarah antara Indonesia dan Filipina kuno telah dimulai sejak sekitar abad ke-9, Prasasti Keping 
Tembaga Laguna dari tahun 900 M menyebutkan Kerajaan Medang di Jawa dan kerajaan Sriwijaya. Sistem penulisan yang digunakan adalah aksara Jawa Kuno, sedangkan bahasa yang digunakan adalah campuran bahasa Melayu Kuno, dan berisi banyak kata-kata pinjaman dari bahasa Sansekerta dan unsur kosakata nonMelayu, beberapa dari Tagalog kuno dan Bahasa Jawa Kuno. Sejak proklamasi kemerdekaan Indonesia pada 17 Agustus 1945 dan kemerdekaan Filipina pada tanggal 4 Juli 1946, hubungan baik antara Indonesia dan Filipina dibangun kembali. Hubungan Indonesia dan Filipina adalah hubungan diplomatik bilateral dan semangat kekeluargaan yang secara resmi dimulai pada 24 November 1949. Kedua negara telah mendirikan kedutaan besar di masing-masing ibukota, Indonesia memiliki kedutaan mereka di Jakarta dan konsulat di Davao City, sementara Filipina memiliki kedutaan mereka di Jakarta dan konsulat di Manado dan Surabaya.

Untuk melembagakan hubungan antara kedua negara, perjanjian persahabatan ditandatangani pada tanggal 21 Juni 1951. Perjanjian ini merupakan hubungan dasar antara kedua negara, yang meliputi beberapa aspek seperti pemeliharaan perdamaian dan persahabatan, penyelesaian sengketa melaui cara damai diplomatik, pengaturan lalu lintas untuk warga kedua negara, dan kegiatan untuk meningkatkan kerjasama di bidang perdagangan, budaya, pengiriman, dan lain-lain, yang meliputi politik, masalah sosial-ekonomi dan keamanan kedua negara.

Pada tahun 1967, kedua negara (bersama-sama dengan Thailand, Singapura, dan Malaysia) mendirikan ASEAN untuk menjamin perdamaian dan stabilitas di kawasan. Kedua negara adalah pendiri ASEAN dan anggota Gerakan Non-Blok dan APEC. Kedua negara juga membangun hubungan yang semakin luas dalam forumforum regional dan multilateral seperti APEC, ASEM, East Asia Summit (EAS, East ASEAN Growth Area (BIMP-EAGA). Kedua negara memiliki komitmen untuk mendorong terciptanya perdamaian, keamanan, stabilitas dan kemakmuran, khususnya di kawasan Asia Tenggara dan Asia Pasifik. Pada tahun 2014 ini, kedua negara akan memperingati 65 tahun dibukanya hubungan diplomatik.

Terdapat beberapa hubungan spesifik Indonesia dan Filipina, baik dari aspek ekonomi, keamanan dan lain sebagainya, antara lain: (Disarikan dari beberapa sumber, antara lain: 1) Republika, Senin, 24 Februari 2014; 2) Widodo AS, Pembangunan Wilayah Perbatasan/Pulau Terdepan Berkaitan Dengan Integritas Nasional, Laporan Rapat Kerja dengan DPR RI, Jakarta, 26 Pebruari 2007; 3) Alex Retraubun, Pulau-pulau Kecil Terluar yang Menjadi Perhatian Khusus, Ditjen Kelautan, Pesisir dan Pulau, Departemen Kelautan dan Perikanan, 2007; 4) Sadina, Perlu Penampakan Kedaulatan RI di Miangas, Sinar Harapan, 9 September 2006; 5) Varrianto Madjowa, Nusa: Pulau Miangas Belum Sepenuhnya Milik Indonesia, Tempo, 12 Pebruari 2003; dan 6) Paulus Londo, Status Pulau Miangas Dalam Perspektif Sejarah, Majalah Cakrawala TNI-AL, 26 April 2006).

\section{Kerjasama Bidang Politik dan Keamanan}

Selama ini hubungan politik Indonesia-Filipina berjalan baik. Di antara kedua negara terdapat saling pengertian yang cukup tinggi dalam penyelesaian mengenai berbagai masalah, baik dalam konteks bilateral, regional maupun 
internasional. Pemeliharaan hubungan tersebut diperkuat dengan kegiatan saling kunjung antarpemimpin kedua negara. Pemimpin kedua negara juga mengadakan pertemuan bilateral di sela-sela forum regional dan multilateral. Kunjungan terakhir PresidenYudhoyono ke Filipina adalah pada 10-14 Januari 2007, dalam rangka menghadiri KTT ASEAN ke-14 di Cebu. Sedangkan kunjungan terakhir Presiden Arroyo ke Indonesia adalah pada saat menghadiri KTT Asia-Afrika di Jakarta, April 2005.

Hubungan bilateral Indonesia dan Filipina terus berkembang dengan dibentuknya Joint Commission for Bilateral Cooperation (JCBC) pada saat kunjungan kenegaraan Presiden Fidel V. Ramos ke Jakarta tahun 1993. Indonesia dan Filipina telah menandatangani tiga kesepakatan dalam pertemuan keenam Komisi Gabungan untuk Kerja Sama Bilateral (JCBC). Salah satu kesepakatan yang ditandatangani dalam pertemuan itu adalah kerja sama di bidang konsuler, yang disebut dengan perjanjian pemberitahuan wajib konsuler (mandatory consular notification agreement). Perjanjian ini penting, seandainya ada warga dari salah satu negara yang mengalami permasalahan bisa saling memberi tahu dengan cepat kepada pemerintahnya, sehingga perlindungan kepada warga negara itu bisa langsung diberikan. Kesepakatan lainnya yang dicapai dalam JCBC keenam itu adalah rencana aksi kedua negara untuk periode 2014-2016. Pihak Indonesia dan Filipina sepakat secara tentatif dan sementara untuk mencapai hasil tentang penetapan batas laut bagi zona ekonomi eksklusif.

Indonesia berperan aktif dalam membantu proses perdamaian di Filipina Selatan, antara lain dengan keikutsertaan Indonesia dalam menyelesaikan proses perdamaian Pemerintah Filipina dengan kelompok Moro National Liberation Front (MNLF). Indonesia juga mendapat kepercayaan dari Organisasi Konferensi Islam (OKI) untuk menjadi Ketua Peace Committee for Southern Phillipines (PCSP). Sementara Filipina telah berperan untuk membantu Indonesia dalam negosiasi dengan pemberontak, dan berperan sebagai monitor selama Proses Perdamaian Aceh pada tahun 2005 .

Indonesia dan Filipina bekerja sama untuk mengeksplorasi cara-cara memerangi terorisme dan bentuk-bentuk kejahatan transnasional lain yang mengancam perbatasan mereka dan secara lebih luas di Asia Tenggara, termasuk terorisme, penyelundupan barang dan jasa, penyelundupan manusia, perdagangan gelap, narkotika, penyanderaan, gerakan terorisme regional. Kesepakatan juga meliputi peningkatan kerjasama kepolisian, intelijen, militer, imigrasi, maupun kepabeanan, dengan saling menukar informasi, komunikasi, dan konsultasi.

Indonesia dan Filipina berbagi perbatasan maritim terutama pada Laut Sulawesi. Pada bulan Maret 2011, para pemimpin dari kedua negara sepakat untuk menandatangani nota kesepahaman untuk meningkatkan kerjasama di bidang keamanan, pertahanan, perbatasan, perlindungan pekerja migran, pendidikan dan olahraga. Indonesia memberi dukungan kepada proposal Filipina untuk menggariskan dan memisahkan bagian-bagian yang dipersengketakan di Laut Cina Selatan dari klaim daerah yang tak terbantahkan dalam penyusunan Kode Tata Berperilaku yang akan mengikat negara-negara yang mempersengketakan kepulauan Spratly. 


\section{Kerjasama Bidang Ekonomi, Perdagangan dan Investasi}

Secara umum hubungan perdagangan Indonesia dan Filipina berkembang secara positif, sesuai dengan keadaan perekonomian di masing-masing negara. Departemen Perdagangan RI mencatat bahwa nilai total perdagangan IndonesiaFilipina pada 2008 mencapai US\$2,8 milyar, dengan surplus sebesar US\$1,29 milyar bagi Indonesia. Angka tersebut merupakan peningkatan 27 persen dari total perdagangan pada 2007 senilai US\$2,2 milyar. Sementara dalam kurun JanuariApril 2009, tercatat total perdagangan sebesar US\$759 juta, dengan surplus sebesar US\$525 juta bagi Indonesia.

Posisi kedua negara yang berada di daerah tropis dan subtropis menjadikan kerjasama di bidang pertanian dan kehutanan sebagai salah satu sektor andalan. Kesamaan beberapa produk pertanian dan kehutanan merupakan komoditi penting dalam perdagangan kedua negara. Kedua negara juga mengembangkan kerjasama di bidang perikanan, pertanian.

Di bidang investasi, realisasi penanaman modal Filipina di Indonesia tergolong masih kecil. Namun Indonesia terus berupaya mengundang para investor Filipina untuk berinvestasi di Indonesia, khususnya di Kawasan Ekonomi Khusus (KEK) di Batam, Bintan dan Karimun.

\section{Kerjasama Bidang Sosial, Budaya dan Pariwisata}

Indonesia dan Filipina memiliki potensi besar untuk mengembangkan kerjasama di bidang pariwisata. Untuk itu kedua negara telah menandatangani $M o U$ on Tourism pada 12 November 2001. Di bawah kerangka kerjasama tersebut, kedua negara menempuh langkah-langkah promosi dan pemasaran bersama. Untuk memfasilitasi peningkatan arus wisatawan, bisnis dan people-to-people contacts, RI dan Filipina perlu membuka lebih banyak jalur perhubungan udara dan laut. Selanjutnya dalam Forum Pariwisata ASEAN 2012 di Manado, Sulawesi Utara, Pemerintah Indonesia dan Filipina memulai kerjasama pariwisata bilateral pertama mereka. Prakarsa ini akan meningkatkan konektivitas antara kedua negara dengan mengoperasikan kapal pesiar dan pembukaan jalur penerbangan langsung antara Davao di Filipina ke Manado. Kedua negara aktif mendukung Master Plan ASEAN Connectivity, yang akan meningkatkan mobilitas yang lebih besar di kawasan ini.

Dalam kerjasama di bidang informasi, RI-Filipina memiliki $M o U$ on Bilateral Cooperation in the Field of Information pada tahun 1996. Kedua pihak berupaya memperbaharui kesepakatan tersebut dengan memasukkan unsur-unsur kerjasama yang lebih luas. RI dan Filipina juga menjalin kerjasama di bidang pengembangan SDM. Hal ini ditempuh dengan penyusunan MoU on Cooperation in the Field of Education and Training. Filipina juga berkeinginan mengembangkan kerjasama antara institusi pendidikan tinggi, khususnya di kawasan yang berbatasan antara kedua negara seperti Mindanao dan sekitarnya.

\section{Kerjasama Bidang-bidang lainnya}

Antara sejumlah kota dan wilayah di RI dan Filipina telah dibentuk kerjasama kota kembar (sister city), yakni Manado-Davao, Bitung-Davao, Sangihe dan Kepulauan Talaud Regency-General Santos City. 
Baik kepulauan Indonesia dan Filipina adalah kawasan yang rentan terhadap bencana alam, seperti gempa bumi, letusan gunung berapi, tsunami, dan topan. Dalam semangat solidaritas dan kemanusiaan, kedua negara sering saling membantu dalam waktu kesulitan. Pemerintah Indonesia pada tanggal 10 Desember 2012 membantu ribuan korban Topan "Pablo" (Bopha) di Visayas dan Mindanao, dengan menyumbangkan \$1 juta dan empat ton barang-barang bantuan melalui Angkatan Bersenjata Filipina. Selain bantuan keuangan, pemerintah Indonesia juga memberikan 1000 selimut militer, 3000 bungkus siap makan saji dan 50 kotak mie instan.

Pada November 2013, Pemerintah Indonesia mengirimkan bantuan kemanusiaan berupa barang dan logistik senilai \$1 million untuk membantu korban Topan Haiyan di Filipina Tengah sebagai bagian dari solidaritas ASEAN. PMI juga mengirimkan bantuan darurat sebanyak 688.862 ton. Tiga Pesawat Hercules TNI Angkatan Udara dikerahkan membawa pasokan ke daerah yang terkena dampak bencana. Bantuan logistik termasuk pesawat, makanan, generator dan obat-obatan. Palang Merah Indonesia junga mengerahkan kapal kargo KM Emir sarat dengan muatan persediaan darurat dan juga 30 relawan Palang Merah Indonesia.

Kerjasama lain meliputi pengembangan balai latihan kerja untuk mempersiapkan tenaga kerja Indonesia (TKI), khususnya tenaga kerja wanita (TKW) agar lebih kompetitif dan mendapatkan perlindungan yang baik selama bekerja di luar negeri. Pemerintah Filipina juga membantu sekitar 8000 warganegara Indonesia yang tidak memiliki dokumen (undocumented) jelas yang tinggal di Filipina Selatan.

\section{Pembahasan}

Meskipun hubungan Indonesia dan Filipina nampaknya telah terjalin baik, namun kesepakatan tentang batas maritim antara Indonesia dengan Filipina perlu menjadi satu isu yang harus dicermati. Berdasarkan inventarisasi yang telah dilakukan oleh DISHIDROS TNI AL, bahwa Pulau Miangas merupakan salah satu pulau terluar di Provinsi Sulawesi Utara yang harus mendapatkan perhatian. Sedangkan Gubernur Sulawesi Utara, mengatakan bahwa Pulau Miangas dan pulau kecil terluar lainnya harus dijaga baik dengan mengedepankan pembangunan secara optimal sehingga masyarakat bisa hidup sejahtera di bawah naungan Negara Kesatuan RI. ( http://nasional.kompas.com/read/ diposkan kembali oleh Dinamis Blog pada 2 Januari 2014).

Memperhatikan uraian di atas dan penggunaan metode analisis SWOT (Strengths, Weaknesses, Opportunities, Threats), maka terdapat sepuluh strategi kebijakan dalam mengamankan Pulau Miangas Provinsi Sulawesi Utara, yaitu:

1) Mengupayakan pengakuan Pulau Miangas secara de jure oleh Pemerintah Filipina melalui pendekatan diplomatic

2) Mengupayakan pencarian dukungan pengakuan dari Negara lain, baik secara de fakto maupun de jure

3) Meningkatkan sistem pertahanan dan keamanan 
4) Meningkatkan kapasitas depot logistic di Pulau Miangas

5) Meningkatkan aksesibilitas masyarakat ke daerah-daerah di Indonesia maupun ke Filipina

6) Mengembangkan produk dan promosi hasil-hasil sumber daya, budaya dan wisata Pulau Miangas

7) Menjunjung tinggi pemakaian bahasa Indonesia dan bahasa daerah Miangas serta mata uang Rupiah

8) Membina hubungan kerja sama perdagangan yang kondusif dan progresif dengan Filipina

9) Memberi aksesibilitas masyarakat Pulau Miangas ke Filipina dengan ketentuan yang ketat, demikian pula sebaliknya

10) Mengupayakan pendekatan persuasif dan komunikasi dengan para tokoh agama atau adat Pulau Miangas.

Selanjutnya untuk mengetahui prioritas kebijakan dalam mengamankan Pulau Miangas berdasarkan sepuluh faktor strategi kebijakan tersebut di atas, maka dilakukan penilaian yang menyangkut dua hal kriteria yaitu kinerja (performance) Pemerintah Pusat dan Daerah hingga tahun 2017, dan tingkat kepentingan (importance) bagi masyarakat Pulau Miangas, akan dihasilkan sebagaimana tabel 2 dan 3 berikut ini.

Tabel 2

Strategi Kebijakan Dalam Mengamankan Pulau Miangas Berdasarkan Kriteria Performance

\begin{tabular}{|c|l|c|}
\hline No. & \multicolumn{1}{|c|}{$\begin{array}{c}\text { Strategi Kebijakan Dalam Mengamankan } \\
\text { Pulau Miangas }\end{array}$} & $\begin{array}{c}\text { Kriteria } \\
\text { Kinerja hingga } \\
\text { tahun 2017 }\end{array}$ \\
\hline 1 & $\begin{array}{l}\text { Mengupayakan pengakuan Pulau Miangas secara de } \\
\text { jure oleh Pemerintah Filipina melalui pendekatan } \\
\text { diplomatic. }\end{array}$ & Tinggi \\
\hline 2 & $\begin{array}{l}\text { Mengupayakan pencarian dukungan pengakuan dari } \\
\text { Negara lain, baik secara de fakto maupun de jure }\end{array}$ & Tinggi \\
\hline 3 & $\begin{array}{l}\text { Meningkatkan sistem pertahanan dan keamanan } \\
\text { Rendah }\end{array}$ \\
\hline 4 & $\begin{array}{l}\text { Meningkatkan kapasitas depot logistic di Pulau } \\
\text { Miangas }\end{array}$ & $\begin{array}{l}\text { Meningkatkan aksesibilitas masyarakat ke daerah- } \\
\text { daerah di Indonesia maupun ke Filipina }\end{array}$ \\
\hline 6 & $\begin{array}{l}\text { Mengembangkan produk dan promosi hasil-hasil } \\
\text { sumber daya, budaya dan wisata Pulau Miangas }\end{array}$ & Rendah \\
\hline
\end{tabular}




\begin{tabular}{|c|l|c|}
\hline 7 & $\begin{array}{l}\text { Menjunjung tinggi pemakaian bahasa Indonesia dan } \\
\text { bahasa daerah Miangas serta mata uang Rupiah }\end{array}$ & Rendah \\
\hline 8 & $\begin{array}{l}\text { Membina hubungan kerja sama perdagangan yang } \\
\text { kondusif dan progresif dengan Filipina }\end{array}$ & Tinggi \\
\hline 9 & $\begin{array}{l}\text { Memberi aksesibilitas masyarakat Pulau Miangas ke } \\
\text { sebaliknya dengan ketentuan yang ketat, demikian pula }\end{array}$ \\
\hline 10 & $\begin{array}{l}\text { Mengupayakan pendekatan persuasif dan komunikasi } \\
\text { dengan para tokoh agama atau adat Pulau Miangas }\end{array}$ & Tinggi \\
\hline
\end{tabular}

Sumber: Hasil Analisis.

Tabel 3

Strategi Kebijakan Dalam Mengamankan Pulau Miangas Berdasarkan Kriteria Importance

\begin{tabular}{|c|l|c|}
\hline No. & \multicolumn{1}{|c|}{$\begin{array}{c}\text { Strategi Kebijakan Dalam Mengamankan } \\
\text { Pulau Miangas }\end{array}$} & $\begin{array}{c}\text { Kriteria } \\
\text { Importance }\end{array}$ \\
\hline 1 & $\begin{array}{l}\text { Mengupayakan pengakuan Pulau Miangas secara de } \\
\text { jure oleh Pemerintah Filipina melalui pendekatan } \\
\text { diplomatic. }\end{array}$ & Tinggi \\
\hline 2 & $\begin{array}{l}\text { Mengupayakan pencarian dukungan pengakuan dari } \\
\text { Negara lain, baik secara de fakto maupun de jure }\end{array}$ & Tinggi \\
\hline 3 & $\begin{array}{l}\text { Meningkatkan sistem pertahanan dan keamanan } \\
\text { Tinggi }\end{array}$ & Tinggi \\
\hline 4 & $\begin{array}{l}\text { Meningkatkan kapasitas depot logistic di Pulau } \\
\text { Miangas }\end{array}$ & $\begin{array}{l}\text { Meningkatkan aksesibilitas masyarakat ke daerah- } \\
\text { daerah di Indonesia maupun ke Filipina }\end{array}$ \\
\hline 6 & $\begin{array}{l}\text { Mengembangkan produk dan promosi hasil-hasil } \\
\text { sumber daya, budaya dan wisata Pulau Miangas }\end{array}$ & Tinggi \\
\hline 7 & $\begin{array}{l}\text { Menjunjung tinggi pemakaian bahasa Indonesia dan } \\
\text { bahasa daerah Miangas serta mata uang Rupiah }\end{array}$ & $\begin{array}{l}\text { Rendah } \\
\text { kendusif dan progresif dengan Filipina }\end{array}$ \\
\hline 9 & $\begin{array}{l}\text { Memberi aksesibilitas masyarakat Pulau Miangas ke } \\
\text { Filipina dengan ketentuan yang ketat, demikian pula } \\
\text { sebaliknya }\end{array}$ \\
\hline 10 & $\begin{array}{l}\text { Mengupayakan pendekatan persuasif dan komunikasi } \\
\text { dengan para tokoh agama atau adat Pulau Miangas }\end{array}$ & Rendah \\
\hline
\end{tabular}

Sumber: Hasil Analisis. 
Dengan memperhatikan tabel 2 dan 3 di atas, skenario prioritas strategi kebijakan dalam mengamankan Pulau Miangas akan merujuk pada matriks kinerja (performance) vs tingkat kepentingan (importance) sebagaimana tabel 4 berikut.

Tabel 4

Matriks Skenario Strategi Kebijakan Dalam Mengamankan Pulau Miangas Menurut Kriteria Kinerja dan Tingkat Kepentingan

\begin{tabular}{|l|l|l|l|}
\hline \multicolumn{2}{|c|}{} & \multicolumn{2}{|l|}{ Performance } \\
\cline { 3 - 4 } \multicolumn{2}{|c|}{} & Rendah & Tinggi \\
\hline \multirow{3}{*}{ Importance } & Tinggi & I & II \\
\cline { 2 - 4 } & Rendah & III & IV \\
\hline
\end{tabular}

Memperhatikan matriks di atas, skenario prioritas strategi kebijakan dalam mengamankan Pulau Miangas menurut kriteria kinerja dan tingkat kepentingan adalah sebagai berikut:

I. Pemerintah Pusat dan Daerah mengkonsentrasikan pada upaya-upaya perbaikan dan memprioritaskannya.

II. Pemerintah Pusat dan Daerah melakukan upaya-upaya untuk mempertahankan kinerja yang telah baik.

III. Pemerintah Pusat dan Daerah dapat menunda upaya-upaya perbaikan atau pembenahan.

IV. Pemerintah Pusat dan Daerah dapat mengabaikan upaya-upaya perbaikan dan pembenahan.

Berdasarkan skenario di atas, maka dengan metode perbandingan berpasangan dihasilkan penilaian sebagai berikut:

Tabel 5

\section{Prioritas Strategi Kebijakan Dalam Mengamankan Pulau Miangas Menurut Kriteria Kinerja dan Tingkat Kepentingan}

\begin{tabular}{|c|l|c|}
\hline No. & $\begin{array}{l}\text { Strategi Kebijakan Dalam Mengamankan } \\
\text { Pulau Miangas }\end{array}$ & Skenario \\
\hline 1 & $\begin{array}{l}\text { Mengupayakan pengakuan Pulau Miangas secara de } \\
\text { jure oleh Pemerintah Filipina melalui pendekatan } \\
\text { diplomatic. }\end{array}$ & II \\
\hline 2 & $\begin{array}{l}\text { Mengupayakan pencarian dukungan pengakuan dari } \\
\text { Negara lain, baik secara de fakto maupun de jure }\end{array}$ & II \\
\hline 3 & Meningkatkan sistem pertahanan dan keamanan & I \\
\hline 4 & $\begin{array}{l}\text { Meningkatkan kapasitas depot logistic di Pulau } \\
\text { Miangas }\end{array}$ & I \\
\hline 5 & Meningkatkan aksesibilitas masyarakat ke daerah- & \\
\hline
\end{tabular}




\begin{tabular}{|c|l|c|}
\hline & daerah di Indonesia maupun ke Filipina & I \\
\hline 6 & $\begin{array}{l}\text { Mengembangkan produk dan promosi hasil-hasil } \\
\text { sumber daya, budaya dan wisata Pulau Miangas }\end{array}$ & III \\
\hline 7 & $\begin{array}{l}\text { Menjunjung tinggi pemakaian bahasa Indonesia dan } \\
\text { bahasa daerah Miangas serta mata uang Rupiah }\end{array}$ & II \\
\hline 8 & $\begin{array}{l}\text { Membina hubungan kerja sama perdagangan yang } \\
\text { kondusif dan progresif dengan Filipina }\end{array}$ & II \\
\hline 9 & $\begin{array}{l}\text { Memberi aksesibilitas masyarakat Pulau Miangas ke } \\
\text { sebalikna dengan ketentuan yang ketat, demikian pula }\end{array}$ \\
\hline 10 & $\begin{array}{l}\text { Mengupayakan pendekatan persuasif dan komunikasi } \\
\text { dengan para tokoh agama atau adat Pulau Miangas }\end{array}$ \\
\hline
\end{tabular}

Sumber: Metode perbandingan berpasangan.

Bertolak dari telaahan di atas, terdapat beberapa alternatif skenario prioritas strategi kebijakan dalam mengamankan Pulau Miangas yang dituangkan menjadi tiga bentuk, yaitu:

I. Pemerintah Pusat dan Daerah mengkonsentrasikan pada upaya-upaya perbaikan dan memprioritaskannya.

II. Pemerintah Pusat dan Daerah melakukan upaya-upaya untuk mempertahankan kinerja yang telah baik.

III. Pemerintah Pusat dan Daerah dapat menunda upaya-upaya perbaikan atau pembenahan.

Dari ketiga skenario prioritas strategi kebijakan dalam mengamankan Pulau Miangas di atas, maka skenario utama yang harus dilakukan Pemerintah Pusat dan Daerah pada saat sekarang ini adalah mengkonsentrasikan pada upaya-upaya perbaikan dan memprioritaskannya terutama: 1) meningkatkan kapasitas depot logistic di Pulau Miangas; 2) meningkatkan aksesibilitas masyarakat ke daerahdaerah di Indonesia maupun ke Filipina; dan 3) mengembangkan produk dan promosi hasil-hasil sumber daya, budaya dan wisata Pulau Miangas.

Skenario utama tersebut di atas tentu terkait dengan konsep batas negara atau perbatasan bahwa perbatasan suatu negara dapat berupa batas alamiah dan batas buatan yang fokus perhatiannya terhadap jaringan, mobilitas, arus globalisasi, dan kosmopolitanisasi berperan dalam mewarnai sifat sebuah kawasan perbatasan, sehingga fungsi Pulau Miangas menjadi penting sebagai salah satu motor pertumbuhan ekonomi (kawasan strategis). Hal ini juga mengingat bahwa berkembangnya borderless diakibatkan adanya efek globalisasi yang menghapuskan batas antar wilayah dalam rangka mengantisipasi gerakan ekonomi yang lebih besar, sedangkan di sisi lain, adanya konsep rebordering dalam rangka pertimbangan keamanan dan kekhawatiran akan perbatasan Pulau Miangas yang terbuka. Konsepsi tersebut berujung pada kontrol yang lebih baik terhadap pergerakan pekerja, pengungsi, dan teroris.

Di sisi lain, dalam konteks akselerasi pertumbuhan pasar global yang mengindikasikan adanya prinsip keterbukaan, bahwa pengembangan Pulau Miangas 
dipandang sebagai suatu hal yang mendesak, hal ini terlihat dari besarnya kesenjangan antara negara kaya dan miskin yang mengarah pada kondisi stabilitas dan keamanan. Perubahan paradigma perbatasan kontemporer dapat dilihat dari pentingnya pendekatan keamanan dalam rangka ancaman global. Upaya ini dapat dipahami sebagai peningkatan kerja sama yang menguntungkan dengan tetap mempertimbangkan faktor keamanan dalam mengantisipasi dampak kerugian yang muncul akibat prinsip keterbukaan di Pulau Miangas. Oleh karena itu, mekanisme pengawasan yang dilakukan oleh Indonesia seharusnya lebih intensif pada kawasan perbatasan, meskipun mungkin secara geografis berada pada wilayah yang terpencil (remote area) dan berada di tapal batas kewenangan teritorial.

Sementara itu, pembangunan Pulau Miangas dapat dilaksanakan secara overlapping dengan demarkasi, karena kendala dan dinamika yang terjadi di Pulau Miangas terkait aspek ekonomi, sosial, budaya dan politik, sehingga sangat lazim untuk melakukan kerja sama dengan Negara tetangga di berbagai sektor tersebut. Mengingat pemahaman mengenai perbatasan jauh lebih komplek, karena keterkaitan yang sangat erat antara aspek fisik dan masyarakat yang menempati wilayah tersebut dan dengan negara, kegiatan ekonomi, dan budaya setempat, maka pertimbangan kekuatan pasar dan arus perdagangan (market forces and trade flows) sangat penting bagi Pulau Miangas karena menyangkut fungsi ekonomi perbatasan. Meskipun demikian pengelolaan Pulau Miangas seharusnya tidak didominasi oleh kepentingan untuk mengeksploitasi fungsi ekonomi perbatasan semata, melainkan perlu juga pertimbangan faktor lainnya seperti keamanan, migrasi penduduk (terutama pencari kerja illegal), penyelundupan, perdagangan gelap obat-obatan, perdagangan manusia, dan sebagainya. Sedangkan dari sisi pengaruh faktor politis masyarakat di Pulau Miangas (the particular political clout of borderland communities) berarti hasil-hasil sumber daya, budaya dan wisata Pulau Miangas harus memperhatikan suara-suara dari masyarakat setempat dan juga berbagai organisasi sosial kemasyarakatan yang ada. Hal ini agar tata kelola Pulau Miangas nantinya tidak berdampak pada kerusakan jaringan sosial yang sudah ada di dalam mayarakat setempat. Dengan kata lain, tata kelola Pulau Miangas harus memperhatikan suara masyarakat lokal, terutama menyangkut bagaimana masyarakat ingin berhubungan dengan para kerabatnya di "seberang" sana. Dengan demikian, pengelolaan Pulau Miangas perlu pula memperhatikan dan dituntut peka terhadap rasa memiliki masyarakat, yang dipisahkan oleh garis "politis" maupun "geografis" perbatasan.

Skenario utama tersebut di atas juga terkait dengan landasan terbentuknya suatu Negara yang terdiri dari dua bagian, yaitu unsur pokok (konstitutif) dan unsur deklaratif. Unsur pokok adalah unsur yang paling penting, karena merupakan syarat wajib yang harus dimiliki oleh calon negara. Berdirinya suatu negara terdiri atas unsur-unsur pembentuknya yang tidak dimiliki oleh organisasi lain. Unsur pembentuk berdirinya suatu negara, yaitu rakyat, wilayah, pemerintah yang berdaulat. Ketiga unsur ini disebut unsur pokok yang menjadi syarat mutlak terbentuknya negara. Suatu negara tidak dapat disebut sebagai negara jika salah satu unsur ini tidak ada. Unsur pokok negara ini disebut juga unsur konstitutif atau unsur pembentuk Unsur deklaratif adalah unsur tambahan yang boleh-boleh saja tidak dimiliki oleh suatu negara. Selain unsur pokok, terdapat pula unsur lain yang menjadi pembentuk suatu negara, yaitu pengakuan dari negara lain. Sedangkan 
pengakuan dari negara lain merupakan unsur negara yang bersifat deklaratif atau bersifat menerangkan keberadaan suatu negara. Suatu negara baru penting untuk menerangkan keberadaannya agar dikenali oleh negara lainnya. Fungsinya adalah agar negara baru tersebut dapat menjalin hubungan diplomatis dengan negara lainnya, begitupun sebaliknya. Secara lebih jelasnya, hal ini sebagaimana konvensi tahun 1933 yang mengatur tentang apa-apa yang harus dimiliki untuk membentuk suatu negara, disebut Konvensi Montevideo. Menurut konvensi ini, unsur-unsur berdirinya sebuah negara adalah sebagai berikut: (1) Rakyat; (2) Wilayah yang permanen; (3) Penguasa yang berdaulat; (4) Kesanggupan berhubungan dengan negara lain; dan (5) Pengakuan. (Murtono, Sri, dkk, 2007:35)

Memperhatikan teori terbentuknya Negara dan peran penting wilayah perbatasan (Pulau Miangas) di atas, maka bentuk-bentuk perlakuan strategi yang dapat dilakukan antara lain meningkatkan fungsi-fungsi: (1) militer-strategis; (2) ekonomis; (3) identitas; dan (4) pembangunan Negara dan kepentingan domestic (Gunawatyi Wuryandari, 2009:36-37). Terkait fungsi militer-strategis, peningkatan kapasitas depot logistic di Pulau Miangas, merupakan fungsi untuk memenuhi kebutuhan militer strategis suatu Negara, terutama pembangunan sistem pertahanan laut, darat dan udara untuk menjaga diri dari ancaman eksternal. Terkait fungsi ekonomi, peningkatan aksesibilitas masyarakat Pulau Miangas ke daerah-daerah di Indonesia maupun ke Filipina berguna mengembangkan arus modal, perdagangan antarnegara/antar-wilayah, investasi, dan pergerakan barang antarnegara atau antarwilayah. Fungsi ekonomis ini juga memberikan patokan bagi Indonesia untuk mengembangkan produk dan promosi hasil-hasil sumber daya, budaya dan wisata Pulau Miangas. Terkait fungsi identitas Nasional Indonesia, peningkatkan aksesibilitas masyarakat Pulau Miangas ke daerah-daerah di Indonesia maupun ke Filipina merupakan pembawa identitas nasional, selain itu memiliki fungsi pengikat secara emosional terhadap komunitas yang ada dalam teritori tertentu. Kesamaan pengalaman dan sejarah, secara langsung maupun tidak langsung telah mengikat masyarakat Pulau Miangas secara emosional untuk mengklaim identitas dan wilayah tertentu. Terkait fungsi pembangunan Negara dan kepentingan domestic, Pulau Miangas sangat membantu dalam pembangunan dan pengembangan Negara Indonesia karena memberikan kekuatan dan kedaulatan bagi Negara untuk menentukan bagaimana sejarah bangsa dibentuk, menentukan simbol-simbol apa yang dapat diterima secara luas, dan menentukan identitas bersama secara normatif maupun kultural, serta berfungsi untuk memberikan batas geografis bagi upaya Negara untuk mencapai kepentingan nasional di bidang politik, sosial, ekonomi, pendidikan, pembangunan infrastruktur, konservasi energi, dan sebagainya.

\section{E. Simpulan dan Rekomendasi}

Meskipun hubungan bilateral antara Indonesia dan Filipina masih dalam keadaan dinamis dan progresif, tetapi intervensi Negara-negara lain dan rendahnya kondisi sosial-ekonomi masyarakat Pulau Miangas tetap menjadi ancaman pertahanan dan keamanan wilayah NKRI. Oleh karena itu, Pemerintah Indonesia harus melakukan upaya-upaya pengamanan Pulau Miangas secara sinergis, utamanya sesegera mungkin mengupayakan kepemilikan pulau terluar (Pulau Miangas) secara de jure, meningkatkan aksesibilitas serta kehidupan dan 
penghidupan masyarakat Pulau Miangas, dan membina hubungan politik, keamanan, dan perdagangan dengan Filipina secara kondusif pada khususnya.

Terkait dengan simpulan di atas, Kementerian Dalam Negeri; Kementerian Luar Negeri; Kementerian Desa, Pembangunan Daerah Tertinggal, dan Transmigrasi; Kementerian Pertahanan; Kementerian Perdagangan; Kementerian Kelautan dan Perikanan; Kementerian Perindustrian; Kementerian Perhubungan; dan Kementerian terkait lainnya, serta POLRI; TNI; Pemerintah Daerah Provinsi Sulawesi Utara, dan Pemerintah Daerah Kabupaten Kepulauan Talaud, perlu bersinergi untuk mengamankan dan mengembangkan Pulau Miangas secara terencana dan berkelanjutan dalam kerangka Negara Kesatuan Republik Indonesia.

\section{F. Daftar Pustaka}

Retraubun, Alex, Pulau-pulau Kecil Terluar yang Menjadi Perhatian Khusus, Ditjen Kelautan, Pesisir dan Pulau, Departemen Kelautan dan Perikanan, 2007.

Arsana, Andi, "Merajut Dinding Maya: Delimitasi Batas Maritim Antara Indonesia-Malaysia." http://ugm.academia.edu, 2010.

Blakely, Edward J, Planning Local Economic Development. Theory and Practice. Sage Publication, 1989.

Direktorat Kelembagaan Internasional, Konstruksi Garis Batas Maritim Indonesia, Ditjen Kelembagaan Peningkatan Kapasitas Kelembagaan dan Pemasaran, Departemen Kelautan dan Perikanan, 2007.

Dye, T.R, Understanding Public Policy (Third Edition). New York. Engelwood Fliffs, 1978.

Faludi, Andreas, A Reader in Planning Theory. Pargamon Press, 1973.

Wuryandari, Ganewati (ed). Keamanan di Perbatasan IndonesiaTimur Leste: Ancaman dan Kebijakan Pengelolaannya. Pustaka Pelajar, Yogyakarta, 2009.

Paulus Londo, Status Pulau Miangas Dalam Perspektif Sejarah, Majalah Cakrawala TNI-AL, 26 April 2006.

Sadina, Perlu Penampakan Kedaulatan RI di Miangas, Sinar Harapan, 9 September 2006.

Hogwood, Brian W and Ldewis A Gunn, Policy Analysis for The Real World. Oxford University Press, 1986. 
IDSPS, Pengelolaan dan Pengamanan Wilayah Perbatasan Negara, Policy Paper, Jakarta, 2009.

J. Gergen, and Bauer, R., The Study of Policy Science, 1968.

Murtono, Sri, dkk. Pendidikan Kewarganegaraan. Jakarta: Quadra, 2007.

Madu, Ludiro, Fauzan dkk. (ed), 2010, Mengelola Perbatasan Indonesia di Dunia Tanpa Batas: Isu, Permasalahan dan Pilihan Kebijakan, Graha Ilmu, Yogyakarta.

Solihin, Abdul Wahab, 2002, Analisis Kebijakan: Dari Formulasi ke Implementasi Kebijakan Negara, (Edisi Kedua), Jakarta: Bumi Karsa.

Suharto, Edi, Analisis Kebijakan Publik. Bandung: Alfabeta, 2005.

Madjowa, Varrianto, Nusa: Pulau Miangas Belum Sepenuhnya Milik Indonesia, Tempo, 12 Pebruari 2003.

AS, Widodo, Pembangunan Wilayah Perbatasan/Pulau Terdepan Berkaitan Dengan Integritas Nasional, Laporan Rapat Kerja dengan DPR RI, Jakarta, 26 Pebruari 2007.

Wu, CT., 2001, “Cross-border Development in Changing World," New Development Paradigm, Vol. 2.

Boggs, Whittermore, 1940, International Bounddaries: A study of Boundary Functions and Problems, New York, Colombia University Press.

Undang Undang Nomor 43 Tahun 2008 tentang Batas Wilayah Negara.

Peraturan Presiden Nomor 78 Tahun 2005 tentang Pengelolaan Pulau-Pulau Terluar.

Republika, Senin, 24 Februari 2014.

http://nasional.kompas.com/read/ diposkan kembali oleh Dinamis Blog pada 2 Januari 2014.

http://www.ppk-kp3k.kkp.go.id/direktori-pulau/index.php/public_c/pulau info/ 306;

http://www.gomanado.com/2015/09/12/8963/shs-dan-forkopimda-sulut-kunjungipulau-terluar-miangas-dan-marore/;

http://www.kompasiana.com/jabri alkatiri/pulau-terluar-miangas-lebih-dekat kefilipina-dari-pada-ke-manado 5518be4e81331197669df0a4; http://infopulau-miangas.blogspot.co.id/. 